\title{
BIOLOGY
}

\section{Influence of hepatoprotectors on the functional state of the liver in laying hens with hepatosis}

\author{
V. Y. Yaremchuk*, L. G. Slivinska \\ Stepan Gzhytskyi National University of Veterinary Medicine and Biotechnologies, Lviv, Ukraine \\ ${ }^{*}$ Corresponding author: E-mail: vasulunkadunets@ukr.ner
}

Paper received 22.12.19; Accepted for publication 30.12.19.

\section{https://doi.org/10.31174/SEND-NT2019-215VII26-06}

Abstract. The article presents the results of influence of "Hep-A-Stress" and "Hepasan-VS" on the functional state of the liver in laying hens in the conditions of scientific and production testing. The results showed that the use of these drugs in to recommended doses $(1 \mathrm{ml} / \mathrm{L}$ of water) has a positive effect on protein and lipid metabolism, cellular enzymes level, purine. These hepatoprotectors stimulate hepatocyte regeneration and possess restorative properties for the liver.

Keywords: liver, laying hens, hepatoprotectors, blood serum, biochemical analysis.

Introduction. Studies of the last three decades in the field of poultry have made it possible to understand the molecular mechanisms of impaired liver function in the conditions of stress in industrial production. Liver disorders have been found to be associated with increased metabolism in the organ during periods of active egg production and, most of all, at peak egg productivity [3, 4].

Understanding the metabolic processes and causes of liver dysfunction helps us to ensure bird health and get productivity with the right quality.

Today the intensive development of poultry and livestock forces the use of new technologies and feeds of excellent quality to achieve high productivity and rapid growth $[6,12,13]$. Often, carbohydrate and fat-rich feed is used to achieve the goals, providing the poultry with a high level of energy. However, it does have negative effects such as heart muscle hypertrophy and fatty liver dystrophy.

Despite the fact that in veterinary practice approaches to complex treatment, with the use of simultaneously different regimens are well-established, the issues of treatment and prevention of hepatosis of hens are still an urgent problem [5].

Hepatoprotectors are the drugs designed to protect the liver from adverse factors, as well as to improve its functions, the ability to "protect" cells of the liver parenchyma (hepatocytes) from damage. Describing the mechanism of their action, it should be noted, that hepatoprotectors don't influence on the disease, but on its pathogenesis. The pathogenesis of liver diseases is based on damage to hepatocytes, which leads to impaired function, dystrophic changes, inflammation, necrosis and fibrosis [8]. The latter result in reduced a productivity, premature culling of the poultry and, has a negative impact on the profitability of production. That's why today the issue of liver protection is urgent and the proper selection and use of an effective hepatoprotector is an important element in complex treatment and preventive measures in poultry.

The aim of this work was to determine and compare the effectiveness of hepatoprotectors "Hep-A-Stress" and "Hepasan-VS" in laying hens with hepatosis.

Material and methods. The researche was conducted in Agro firm "Zagai" of Kamiyanka-Buzkyi district of Lviv region. The objects of study were laying hens of the breed "Lohmann Brown" $(n=4500)$ at the age of 300 days. The hens were kept at the poultry farm in typical rooms, equipped with 3-tier batteries with feeders, planting density 5 heads per cage. All laying hens were in the same conditions of keeping and feeding. The poultry was fed a complete compound feed (main diet (MD)) in accordance to the norms of productivity for laying hens of this age.

Laying hens were divided into three groups, 1500 heads in each. The first group (the control) - received main diet. The hens from the control group were fed with the vitamin-mineral, amino acid and general-stimulating, listed in the technological map the use of poultry. The first experimental group hens were given oral hepatoprotector "Hep-A-Stress" at a dose of $1 \mathrm{ml}$ per 1 liter of drinking water for 10 days. The hens from second experimental group - received main diet and hepatoprotector "Hepasan-VS" at a dose of $1 \mathrm{ml}$ per 1 liter of drinking water for 10 days, using a dispenser. The scheme of research is shown in table 1.

Table 1. Scheme of production-experimental studies to study the effectiveness of hepatoprotectors "Hep-A-Stress" and "Hepasan-VS" in keeping laying hens

\begin{tabular}{|c|c|c|c|}
\hline Animal groups & Scheme of study & $\begin{array}{c}\text { The term of } \\
\text { hepatoprotectors } \\
\text { application }\end{array}$ & $\begin{array}{c}\text { Age of } \\
\text { poultry } \\
\text { (days) }\end{array}$ \\
\hline Control & The main diet & did not give & $300-310$ day \\
\hline Experimental 1 & $\begin{array}{c}\text { The main diet }+1 \\
\mathrm{ml} / \mathrm{L} \text { of water «Hep- } \\
\text { A-Stress» }\end{array}$ & 10 days & $300-310$ day \\
\hline Experimental 2 & $\begin{array}{c}\text { The main diet }+1 \\
\text { ml/L of water } \\
\text { «Hepasan-VS» }\end{array}$ & 10 days & $300-310$ day \\
\hline
\end{tabular}

Most of the hepatoprotectors in the Ukrainine contain carnitine, sorbitol and magnesium sulfate, but the number of active substances (AS) varies from 1 to 5 [1]. The content of active substances in "Hep-A-Stress" and "Hepasan-VS", used in study is presented in fig. 1. 
Fig. 1. The ratio of the content of active substances in $1 \mathrm{ml}$ of the drug «Hep-A-Stress» and «Hepasan-VS», ml

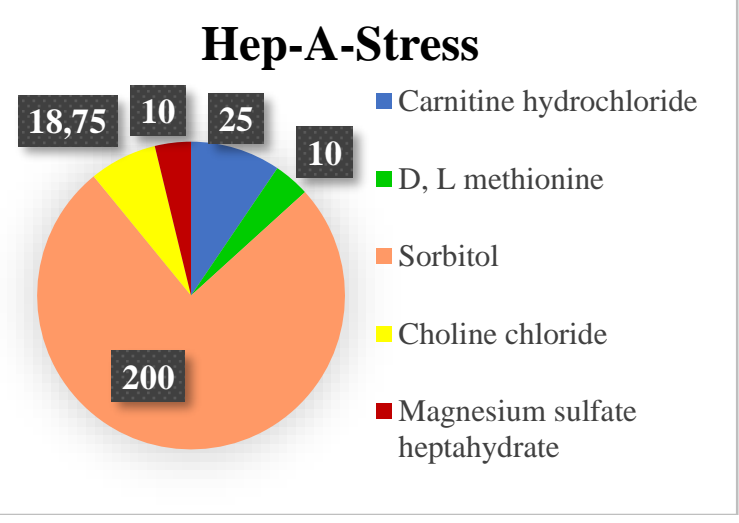

The blood serum was used for tests. Biochemical analysis where performed in our study 30 hens of each group. Sampling of blood from laying hens was performed three times: before drug administration and in 10 and 30 days after the beginning hepatotectors intake. Blood sampling was performed in vivo from the subclavian vein, in compliance with the rules of aseptic and antiseptic, using Vacuette vacuum tubes (Greiner, Austria). The following parameters were determined: content of total protein and its fractions, urea concentration, uric acid, activity of aspartate (AST) and alanine (ALT) aminotransferases, cholesterol.

Determination of the biochemical parameters in the blood serum of poultry was carried out in the laboratory of clinical and biological research of the State Research Institute of Veterinary Drugs and Feed Additives, using a semi-automatic biochemical analyzer «HumaLyzer 3000» using standardized Humanagnostic Germanium kit. The content of total protein was determined using an IRF-22 refractometer. The proteins fractional composition in blood serum was determined by cellulose acetate electrophoresis using a Scan Power 300 and Scanion Lira 400 microprobe electrophoresis apparatus, Hospitex Diagnostics.

The research was conducted in accordance with the provisions of the uropean Convention for the Protection

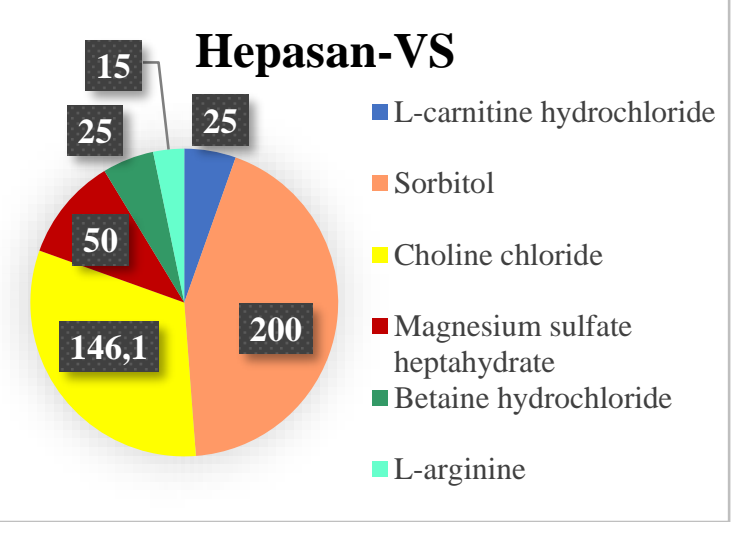

of Vertebrate Animals Used for Experimental and other Scientific Purposes (Strasbourg, 1986), of the provisions on the use of vertebrates for research and other scientific purposes at the Lviv National University of Veterinary Medicine and Biotechnology named after S.Z. Gzhytskyi, of the Ukrainian Law no. 3447-4 "On the Protection of Animals from Cruelty".

The results of biochemical studies are presented in accordance with the International System of Units recommended for clinical laboratory practice and statistically processed using Statistica 6.0 (Stat Soft, Tulsa, USA) and Microsoft Exsel 2016 using the Student's t-test using a statistical program.

Results and discussion. According to the results of study the use of hepatoprotectors "Hep-A-Stress" and "Hepasan-VS" in laying hens during the period of intensive egg-laying stimulates metabolism and has a positive effect on blood parameters.

Determination of total protein in blood serum indicates the level of protein intake with nutrition and the intensity of its synthesis in the liver. The liver account is responsible for the synthesis of $100 \%$ albumin, $80 \%$ blood globulins, fibrinogen, prothrombin, ferritin [2]. Table 2 shows the results of study of the protein profile in the blood serum of laying hens.

Table 2. The content of serum total protein $(\mathrm{g} / \mathrm{L})$ and it fraction $(\%)$ in laying hens. $(\mathrm{M} \pm \mathrm{m}, \mathrm{n}=30)$

\begin{tabular}{|c|c|c|c|c|c|c|c|c|}
\hline \multirow{3}{*}{ 袢 } & \multirow{3}{*}{$\begin{array}{l}\text { The term of } \\
\text { experiment }\end{array}$} & \multirow{3}{*}{$\begin{array}{l}\text { Biometric } \\
\text { indicator }\end{array}$} & \multicolumn{6}{|c|}{ Parameters } \\
\hline & & & \multirow{2}{*}{$\begin{array}{l}\text { Total protein, } \\
\text { g/L }\end{array}$} & \multirow[t]{2}{*}{ Albumin, $\%$} & \multicolumn{4}{|c|}{ Globulins, $\%$} \\
\hline & & & & & $\alpha 1$ & $\alpha 2$ & $\beta$ & $\gamma$ \\
\hline \multirow{3}{*}{ 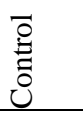 } & before treatment & $\mathrm{M} \pm \mathrm{m}$ & $69,9 \pm 0,25$ & $36,5 \pm 0,63$ & $7,0 \pm 0,22$ & $11,7 \pm 0,45$ & $10,5 \pm 0,52$ & $34,3 \pm 0,88$ \\
\hline & in 10 days & $\mathrm{M} \pm \mathrm{m}$ & $71,8 \pm 0,68$ & $34,0 \pm 0,63$ & $7,6 \pm 0,25$ & $12,8 \pm 0,32$ & $11,0 \pm 0,31$ & $34,7 \pm 0,59$ \\
\hline & in 30 days & $\mathrm{M} \pm \mathrm{m}$ & $72,3 \pm 1,47$ & $33,3 \pm 0,97$ & $9,1 \pm 0,25$ & $12,4 \pm 0,38$ & $14,1 \pm 0,39$ & $31,1 \pm 0,79$ \\
\hline \multirow{3}{*}{ 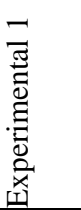 } & before treatment & $\mathrm{M} \pm \mathrm{m}$ & $67,8 \pm 1,05$ & $36,5 \pm 0,64$ & $7,1 \pm 0,22$ & $12,0 \pm 0,33$ & $11,4 \pm 0,44$ & $33,0 \pm 0,78$ \\
\hline & in 10 days & $\mathrm{M} \pm \mathrm{m}$ & $63,8 \pm 0,75^{* * \text { ooo }}$ & $37,2 \pm 0,58^{\circ o}$ & $7,4 \pm 0,22$ & $12,0 \pm 0,28$ & $11,7 \pm 0,40$ & $31,6 \pm 0,52$ \\
\hline & in 30 days & $\mathrm{M} \pm \mathrm{m}$ & $\underset{\text { ooo }}{57,8 \pm 0,33 * * *}$ & $\underset{\text { ooo }}{41,7 \pm 0,33 * * *}$ & $7,0 \pm 0,19$ & $10,7 \pm 0,22$ & $12,7 \pm 0,34$ & $27,9 \pm 0,32$ \\
\hline \multirow{3}{*}{ 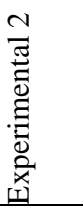 } & before treatment & $\mathrm{M} \pm \mathrm{m}$ & $66,9 \pm 0,77$ & $36,0 \pm 0,40^{\circ}$ & $7,1 \pm 0,31$ & $10,2 \pm 0,33$ & $10,1 \pm 0,49$ & $36,5 \pm 0,80$ \\
\hline & in 10 days & $\mathrm{M} \pm \mathrm{m}$ & $63,4 \pm 1,22 *$ ooo & $37,1 \pm 0,34$ & $6,6 \pm 0,24$ & $11,8 \pm 0,37$ & $12,0 \pm 0,41$ & $32,5 \pm 0,46$ \\
\hline & in 30 days & $\mathrm{M} \pm \mathrm{m}$ & $\underset{\text { ooo }}{58,3 \pm 0,36 * * *}$ & $\underset{\text { ooo }}{40,6 \pm 0,23 * * *}$ & $7,5 \pm 0,31$ & $11,9 \pm 0,33$ & $12,5 \pm 0,44$ & $27,5 \pm 0,34$ \\
\hline
\end{tabular}

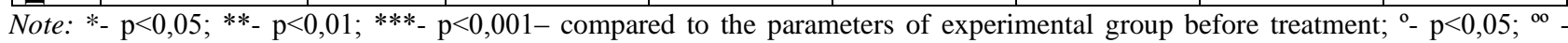
$\mathrm{p}<0,01 ;{ }^{\text {ooo }}$ - $\mathrm{p}<0,001$ - compared to the parameters of control group.

Conducted studies of blood serum of the control group showed an increase of the content of total protein up to
$2.7 \%$ and $3.4 \%(\mathrm{p}<0.05 ; \mathrm{p}=0.1)$, respectively, after 10 and 30 days of treatment and an increase of albumin con- 
tent on $7.4 \%$ and $9.6 \%(\mathrm{p}<0.05)$. Such changes indicate impaired protein synthesis and further development of dystrophic processes in the liver.

It was found that after 10 days after the start of treatment in the first and second experimental group recorded a slight decrease in total protein content up to $6.3 \%$ and $5.5 \%(\mathrm{p}<0.01 ; \mathrm{p}<0.05)$, respectively. The content of albumin and globulin in the serum did not differ significantly.

After 30 days of treatment, the content of total protein in the first and in the second experimental groups decreased on $17.3 \%$ and $14.8 \%(\mathrm{p}<0.001)$ compared to parameters before treatment and was lower than that of the control group, namely on $25.1 \%$ and $24 \%(\mathrm{p}<0.001)$, respectively. The serum albumin content in laying hens in the experiment groups increased on $14.2 \%$ and $12.7 \%$ $(\mathrm{p}<0.001)$, respectively, comparing with the level before treatment due to a decrease in globulin fractions.

The serum activity of cellular enzymes - aminotransferases was determined, which reflect the functional state of the liver. They are participating in the processes of transamination, transfer amino groups from amino acids to keto acids [9]. The content of AST and ALT in hepatocytes and the rate of their exit from cells during physiological regeneration of the liver have strong influence on the activity of these enzymes in the blood of hens, as well as on the intensity and direction of amino acid transformations, which, in turn influences on the egg productions. [11].

Aspartate aminotransferase is one of the enzymes belonging to the aminotransferase group. Table 3 shows that AST activity in the control and two experimental groups was high at the beginning of the experiment and averaged $200.3 \pm 2.06 ; 214.3 \pm 1.88 ; 211.3 \pm 2.17 \mathrm{U} / \mathrm{L}$, respectively. In 10 days after treatment, this parameter had a pronounced tendency to decrease, in the first experimental group - on $6,1 \%$ and in the second - on $4 \%(\mathrm{p}<0,05)$. After 30 days of the experiment, the activity of AST in both study groups continued to decrease $(\mathrm{p}<0.001)$ and was $25.2 \%$ and $21.0 \%$ lower relatively to the initial values. It should be noted that after the third blood sampling, this indicator was $17.9 \%$ and $15.6 \%$ lower in the first and second experimental groups relatively to the control group.

Table 3. Activity of aminotransferases in serum blood in laying hens $(\mathrm{M} \pm \mathrm{m}, \mathrm{n}=30)$

\begin{tabular}{|c|c|c|c|}
\hline \multirow{2}{*}{ Animal group } & \multirow{2}{*}{$\begin{array}{c}\text { Before } \\
\text { treatment }\end{array}$} & \multicolumn{2}{|c|}{ Studies days } \\
\hline & & in 10 days & in 30 days \\
\hline \multicolumn{4}{|c|}{ AST, U/L } \\
\hline Control & $200,3 \pm 2,06$ & $193,2 \pm 1,48$ & $201,8 \pm 1,54$ \\
\hline Experimental 1 & $214,3 \pm 1,88$ & $202,0 \pm 3,99 * 0$ & $171,2 \pm 0,98 * *$ oо \\
\hline Experimental 2 & $211,3 \pm 2,17$ & $203,1 \pm 3,02 * 0$ & $174,6 \pm 0,90 * *$ оо \\
\hline \multicolumn{4}{|c|}{ ALT, U/L } \\
\hline Control & $8,6 \pm 0,16$ & $8,6 \pm 0,22$ & $11,1 \pm 0,06$ \\
\hline Experimental 1 & $11,1 \pm 0,28$ & $8,3 \pm 0,24 * *$ & $7,4 \pm 0,14 * *$ оo \\
\hline Experimental 2 & $10,6 \pm 0,32$ & $9,7 \pm 0,13 *$ оо & $8,9 \pm 0,18 * *$ оо \\
\hline
\end{tabular}

Before treatment, the ALT activity in the blood serum of laying hens of all groups ranged from $8.6 \pm 0.16$ to $11.1 \pm 0.28 \mathrm{U} / \mathrm{L}$. After feeding the hepatoprotectors, the activity of the enzyme in laying hens from experimental groups had a pronounced tendency to decrease. This indicator decreased in the first experimental group 10 days after treatment on $34 \%$ and after 30 days - on $50 \%$ $(p<0.001)$ relatively to the value of the enzyme before treatment. Changes of ALT activity in the blood serum of the second experimental group were less pronounced (on $8.9 \%(\mathrm{p}<0.05)$ and on $18.7 \%(\mathrm{p}<0.001)$, respectively).

In 30 days after treatment the serum ALT of laying hens in the first experimental group are $(\mathrm{p}<0.001) 50 \%$ lower, and in the second $-24.7 \%$ lower compared to the indicators of the control group.

It should be noted that after treatment, the activity of alanine aminotransferase in serum decreased more significantly than the activity of aspartate aminotransferase. This is due to the fact that ALT is excreted from the membranes of hepatocytes and enters the blood, whereas AST is contained in the mitochondria of hepatocytes, and therefore the penetration of this enzyme into the blood is complicated by the fact that in addition to the cell surface membrane, this enzyme must also penetrate through the mitochondrial membrane.

The cholesterol level is an important indicator of lipid metabolism in which in the liver is actively involved [10, 15]. Before treatment, the serum cholesterol concentration in control, first and second experimental groups was $2.5 \pm$ $0.12 ; 2.1 \pm 0.02 ; 2.1 \pm 0.06 \mathrm{mmol} / \mathrm{L}$, respectively (Fig. 2). 10 days after treatment, the total cholesterol content was 0.1 and 0.2 times lower in the first and second experimental groups compared to the control group. After the use of hepatoprotectors (30 days), the cholesterol content in laying hens of the first experimental group were ( $p$ <0.001) 2.7 times lower compared to the start of the experiment and 2.4 times lower compared to the control group. So, hepatoprotectors had a positive effect on the cholesterol concentration in laying hens of the experimental groups. According to our opinion, lowering cholesterol content is associated with a decrease in the activity of lipolysis and gluconeogenesis, as well as an improvement in bile excretion.

\section{Fig. 2 Dynamic of serum total cholesterol changes in laying hens $(\mathrm{M} \pm \mathrm{m}, \mathrm{mmol} / \mathrm{L})$}

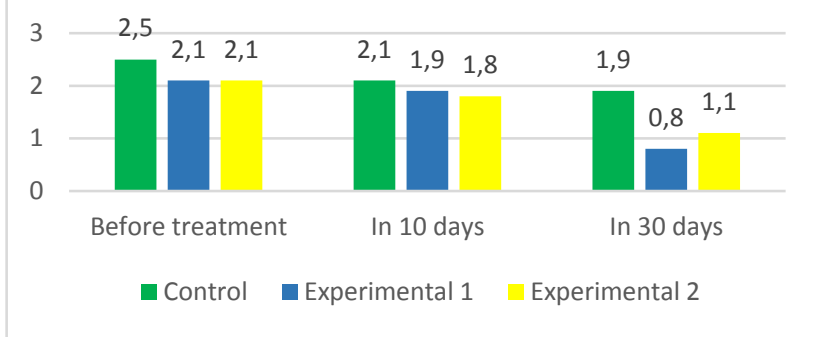

No less pronounced impact of therapeutic measures led to a decrease in the intensification of purine metabolism. The content of serum uric acid in control and experimental groups of laying hens at the beginning of the studies was $430.5 \pm 19.62 ; 356.4 \pm 11.01 ; 339.4 \pm 15.90 \mu \mathrm{mol} / \mathrm{L}$, respectively (Fig. 3 ). In the first experimental group uric acid decreased on $4.1 \%$ and $7.3 \%(\mathrm{p}=0,1)$ after 10 and 30 days of treatment. In the second experiment group, there was no such trend, however, 30 days after treatment, this indicator decreased on $3.7 \%$ compared to the begin- 
ning of the experiment and on $12.6 \%$ compared to the control group.

Fig. 3 The content of serum uric acid in laying hens $(\mathrm{M} \pm \mathrm{m}, \mu \mathrm{mol} / \mathrm{L})$

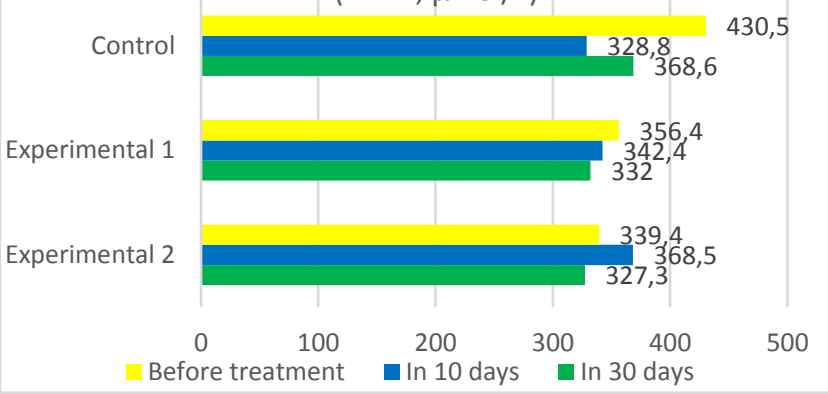

Obviously, such normalization of nucleotide exchange is, first and foremost, related to the pharmacological properties of the constituents of «Hep-A-Stress» and «Hepasan-VS». The decrease of serum uric acid level in laying hens of experimental groups was probably caused by a positive effect of methionine and carnitine hydrochloride on the functional state of hepatocytes, and sorbitol - on the urinary function of the kidneys (enhances diuresis) [7]. Therefore, these hepatoprotectors have a preventive effect on the kidneys and lead to a more intensive excretion of the final products of protein metabolism in the form of uric acid.

Serum level of urea is an important diagnostic test for the assessment of the status of renal excretory function and kidney detoxification function [14]. At all stages of the studies, this indicator in the control group and in the experimental groups had no significant difference and was in the range of $1.7 \pm 0.02-2.1 \pm 0.04 \mathrm{mmol} / \mathrm{L}$ (Fig. 4). Positive changes should be noted in the first experiment group, because, in 30 days after treatment, the urea content increased on $5.3 \%$ compared to the pre-treatment parameters and on $11.1 \%$ compared to the control group.

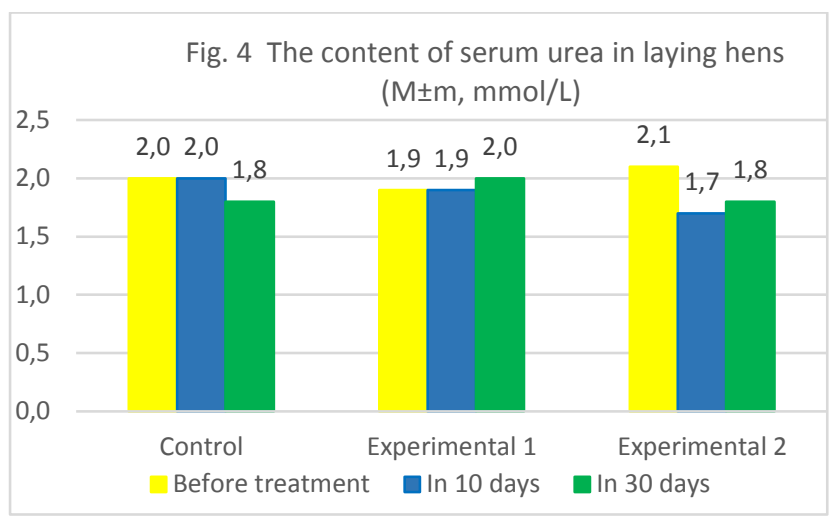

\section{Conclusions}

1. The use of hepatoprotectors in laying hens with hepatosis has a positive effect on protein, lipid, purine metabolism, cellular ensymes levels due stimulation of hepatocyte regeneration.

2. «Hep-A-Stress» is more effective than «Hepasan-VS» in laying hens.

The prospect of further research is to study the impact of this hepatoprotectors within circuits for the prevention of liver diseases caused by metabolic disturbances.

\section{REFERENCES}

1. Avdos'eva I.K., Temnenko S.M., Kalynovs'ka L.V., Zdolyny S.O. Efficiency of hepato-protector hepabialcarnitane at broilers growing / Scientific Messenger of Lviv National University of Veterinary Medicine and Biotechnologies named after S. Z. Gzhytsky, 2014, vol. 16, no. 3(60), part 2, P. 3-11. (in Ukrainian)

2. Danchuk V.V., Nishmenenko M.P., Peleno R.A., Romanko M.E., Ushkalov V.A, Karpovsky V.I. Handbook of general and special methods for the examination of farm poultry blood [Text] /; [edit] V.O. Ushkalov]; Lviv: SPOLOM, 2013 P. 248 (in Ukrainian)

3. Dunets V.Y., Slivinska L.G. Clinical syndromatic of laying hens of cross «Lohmann Brown» in the conditions of farm // Scientific Messenger of Lviv National University of Veterinary Medicine and Biotechnologies named after S. Z. Gzhytsky, 2018, vol. 20, no. 83, P. 341-346. doi: $10.15421 /$ nvlvet8368 (in Ukrainian)

4. Dunets V.Y., Slivinska L.G. The functional condition of the liver in laying hens under hepatosis // The animal biology, 2018, vol.20, no. 3, P. 24-29. doi: 10.15407/animbiol20.03.024

5. Dunets V.Y., Slivinska L.G. The prevention of liver disease in laying hens // Scientific Messenger of Lviv National University of Veterinary Medicine and Biotechnologies named after S. Z. Gzhytsky, 2017, vol. 19, no. 73, P. 55-60. doi: 10.15421/nvlvet7312 (in Ukrainian)

6. Ermashkevich E.I., Kletikova L.V., Evaluation of fitocompozitions in chickens with protein liver disease by biochemical blood tests // Bulletin of Orlov State Agricultural University, 6(62), December, 2016. P. 112-117. doi $10.15217 / 48484$

7. Melnik A.Y. Some propagates of protein-lipid exchange and functional state of liver in kurchat-broilers for the use of "an- imal health" // Scientific Messenger of Veterinary Medicine, 2, 2017. P. 69-78. (in Ukrainian)

8. Nikitin I.G. Hepatoprotectors: Myths and real opportunities // Pharmateka, 2007.- №13 (147) - P. 14-18. (in Russian)

9. Ostapyuk A.Y., Gutyj B.V. Influence of cadmium sulfate at different doses on the functional state of the liver of laying chicken // Scientific Messenger of LNU of Veterinary Medicine and Biotechnologies. Series: Veterinary Sciences, 21(94), P. 103-108. doi: 10.32718/nvlvet9419 (in Ukrainian)

10. Qureshi I.A., Khan S.A., Z. I. Chaudhry, N. A. Mian M. Y. Tipu and M. F. Rai effects of high dietary fat on serum cholesterol and fatty liver syndrome in broilers // Pakistan Vet. J., 24(3): 2004, P. 153-154

11. Sereda T.I., Dercho M.A. The role of aminotransferase activity in hen productivity // Agricultural biology, 2014, no. 2, P. 72-77.

12. Sharonina N.V., Mukhitov A.Z., Shishkov N.K. Some indicators of metabolism in laying hens when feeding soy okara // Bulletin of the Ulyanovsk State Agricultural Academy, 2016, vol. 4, no. 36, P.68-71. doi: 10.18286/1816-4501-2016-4-6871 (in Russian)

13. Thomson, A.E., Gentry, P.A., Squires, E.J. Comparison of the coagulation profile of fatty liver haemorrhagic syndromesusceptible laying hens and normal laying hens // British Poultry Science, 2003, vol. 44, no. 4, P. 626-633. doi: $10.1080 / 00071660310001616228$

14. Uoshebau R. Laboratory diagnosis of liver disease // Veterinary Focus, 2010, vol. 20 (3), P. 32-37. (in Russian)

15. Vlizlo V.V., Slivinska L.H., Maksymovych I.A., Leno M.I., Halias V.L. Laboratory diagnostics in veterinary medicine (reference book): Second edition, revised and supplemented. / Lviv, Afisha, 2014, P. 152 ISBN 978-966-325-201-8. (in Ukrainian) 